\title{
HEIGHT OF THE BAY OF FUNDY COAST IN THE GLACIAL PERIOD RELATIVE TO SEA-LEVEL, AS EVIDENCED BY MARINE FOSSILS IN THE BOWLDER-CLAY AT SAINT JOHN, NEW BRUNSWICK*
}

\author{
BY ROBERT CHALMERS
}

(Read before the Saciety Decemoer 29, 1892)

\section{CONTENTS}

Page
Pand

Locality, Area and Thickness of Bowlder-clay Deposit............... 361

Direction of Striæ on Rocks.................................. 362

Topogtaphy of District North of Bowlder-clay Deposit................ 362

The Bowlder-clay ....................................... 363

Source of the Materials composing it. . . . . . . . . . . . . . . . . 363

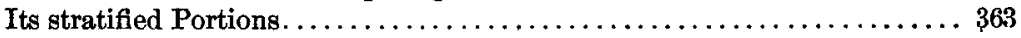

Section at the Fern Ledges............................... 363

Section at Negrotown Roint.............................. 365

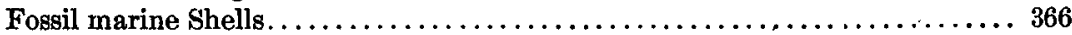

Their Occurrence in the Bowlder-clay at Negrotown Point........... 366

Their Occurrence in the Bowlder-clay of the Saint Lawrence Valley..... 366

Their Occurrence in the Drumlins near Boston............... 367

Their Occurrence in the Leda Clay and Saxicava Sands of New Brunswick. 367 The Height of the Land and, the Mode of Deposition of the Bowlder-clay. . . . 367 Oscillations of the Ice-margin ................................. 369 Climatic Conditions during Deposition of the Leda Clay and Saxicava Sands. . 369 Conclusions .......................................... 369

Discussion......................................... 370

Locality, Area and Thickness of the Bowlder-clay Deposit.

The occurrence of a thick deposit of bowlder-clay on the Bay of Fundy coast just west of Saint John harbor, containing intercalary seams of

* Published by permission of the Director of the Geological Survey of Canada.

LIV-BulL. Grot. Soc. Ax., VoI. 4, 1892. 
stratified clay, was referred to in my report on the surface geology of southern New Brunswick.* This bowlder-clay forms a marginal strip of the land from Carleton to Duck cove, one and a half to two miles in length, and in the bank facing the sea rises from 40 to 60 feet in height above the beach. The part of it jutting out into the bay and forming a headland opposite Partridge island is called Negrotown point. A breakwater has been constructed there. The bowlder-clay at this point attains its greatest width, being 1,033 yards across in a north and south direction. At'the Fern ledges, so called, from three-quarters of a mile to a mile west of the breakwater, it narrows to 215 yards, again widening out, however, before being overlapped at Duck cove, a little beyond, by fossiliferous Leda clay and Saxicava sands. At the Fern ledges the exposed thickness of the bowlder-clay, including the intercalary stratified seams, is by actual measurement $61 \frac{1}{2}$ feet, but its thickness decreases to the eastward.

\section{Direction of Stria on Rocks.}

The ledges which come out on the shore from underneath the bowlderclay here are well striated, the direction of the striæ being S. $2^{\circ} \mathrm{W}$., S. $2^{\circ}$ E., S. $10^{\circ}$ E., S. $20^{\circ}$ E., S. $30^{\circ}$ E., S. $56^{\circ}$ E., S. $60^{\circ}$ E., and S. $65^{\circ}$ E. (true meridian), and several of these courses appearing often on the same surface. The stoss-side is invariably to the north. These divergent striæ are noteworthy and indicate very clearly the action of several bodies of ice as they debouched into the sea.

To the east of the Fern ledges no rock exposures are seen along the shore, and the bottom of the bowlder-clay is covered up by beach sands and by the bowlders and debris which have fallen down as the bank is being eroded by the sea.

Topography of the District noRth of the Bowlder-clay Deposits.

Immediately to the north of this marginal belt of bowlder-clay and occupying the peninsula between the mouth of the Saint John river and the Bay of Fundy lies a group of hills from 175 to 225 feet high, known as Carleton heights. The rock surfaces on many of these are bare and exhibit their highly glaciated condition. The main courses of the striæ are S. $2^{\circ} \mathrm{E}$. and S. $16^{\circ} \mathrm{W}$. (true meridian).

The district around the mouth of the Saint John river has a hilly and broken surface, but the larger portion of it lies, nevertheless, below the 220 -foot contour line. It is a locality which has been very favorably situated for the nourishment of glaciers. Accordingly we find here 
abundant evidence of the former existence of land ice, and, from the position of the striæ and the character of the bowlder-clay, the conclusion that the ice which covered the district flowed out toward the open waters of the Bay of Fundy is beyond question.

\section{THE BOWLDER-CLAY.}

Source of the Materials composing it.-Field investigations reveal the fact that the materials composing the great mass of the bowlder-clay are obviously derived from the rocks lying immediately to the north. These rocks belong to the pre-Cambrian, Cambrian and Carboniferous Bowlders of these systems, consisting of granites, gneisses, Lower Carboniferous conglomerates, diorites or diabases, limestones, sandstones, slates, quartzites, etc., are displayed in the débris along the foot of the bank, strewn upon the beach, and also appear scattered throughout the mass of bowlder-clay. Many of them are large, the great majority being from 3 feet to 8 or 10 feet in diameter, and a considerable number are striated and polished. At Negrotown point the largest bowlders are of Lower Carboniferous conglomerate, the parent rock of which is from 3 to 10 miles to the north.

Clay and gravel, or rock débris, constitute the principal bulk of the bowlder-clay. The uppermost parts are less compacted than the lower and are capped by Saxicava sands in places. This renders it permeable by water to some depth, and, in those parts which contain stratified seams of clay, springs ooze out in the bank. Owing to this fact, and to the foot of the bank being continually eroded by the sea, landslips are of frequent occurrence and rapid denudation of the bowlder-clay is taking place.

Its stratified Portions.- The stratified portions of the bowlder-clay are for the most part thin, and form irregular, lenticular seams in the heart of the unstratified mass. They are distinctly laminated, and in some places, as at the Fern ledges, the strata dip slightly northward, that is, away from the shore. The material is a tough, dark red, brick-clay, containing a few pebbles and bowlders, scarcely any of which exceed 9 inches or a foot in diameter. These stratified bands usually occur in the middle of the bowlder-clay bank, being underlain and overlain by unstratified deposits, often of considerable thickress.

Section at the Fern Ledges.-The following section of the bowlder-clay at the Fern ledges will serve to illustrate its structure and character; it was carefully measured, in descending order, a few feet to the west of the section given in my report above cited: 
1. Unstratified bowlder-clay, with three or more thin seams or layers of clay and. sand interstratified therewith. It contains pebbles and bowlders of all sizes up to 9 inches or a foot in diameter, some of which are striated. The seams of clay and sand dip slightly northward or away from the sea. The uppermost parts contain a good deal of sand, and have apparently been worked over in the Saxicava sand period. The surface of the ground is strewn with bowlders from 2 feet in diameter downward; total thickness, 12.7 feet.

2. Typical, unstratified bowlder-clay, containing numerous glaciated bowlders and pebbles; bowlders from 3 to 5 and 6 feet in diameter are common; thickness, 25 feet.

3. Stratified, tough, dark-red clay, forming a wavy, lenticular seam, distinctly laminated, the strata dipping slightly northwestward, but irregular and uneven, and not occupying a continuous horizontal position, except very locally. To the west of the section it decreases in thickness and runs down to within a few feet of the bottom of the bank; to the east it first rises somewhat higher and then descends likewise, diminishing in thickness till only a foot or two of it can be seen. It contains a few pebbles, and occasionally a bowlder-one 10 inches in diameter was noticed. No fossils were detected in it; thickness in the thickest part, 14 feet.

4. Unstratified bowlder-clay, the same as number 2. Bowlders 3 to 6 feet in diameter are numerous. These are strewn along the foot of the bank as well as upon the beach. The total thickness of this bed is from 9 to 10 feet.

Following this bed (number 4) of bowlder-clay continuously westward from the line of the section we find it, at a distance of 15 paces, resting on the glaciated ledges. Here it is observed, however, to have only a thickness of from 3 to 5 feet. The stratified seam overlying it has, as stated above, also thinned out here, but is, nevertheless, well defined. Striated rocks, with this bed of bowlder-clay reposing on them, extend continuously along the shore for about 90 yards farther west. There is much variation in the direction of the striæ. Eight or more different courses of them occur on these ledges, varying from S. $2^{\circ} \mathrm{W}$. to S. $65^{\circ} \mathrm{E}$. (true meridian). These, it is evident, must all have been produced by the glaciers which laid down the bottom portion of the bowlder-clay (number 4 of the section); for before the ice which deposited the upper portions of the unstratified beds (numbers 2 and 1 of the section) could have striated the rocks it would have to work over the whole of the deposits beneath it, thus destroying all stratification therein and reducing them to a pell-mell mass. 
Section at Negrotown Point.-This section was measured at a distance of about a quarter of a mile west of the Negrotown Point breakwater. In descending order the beds are as follows:

1. Typical bowlder-clay, unstratified, containing bowlders 2 to 5 feet in diameter, most of them glaciated. The total thickness of this bed is 11 feet.

2. An irregular, wavy, lenticular seam of stratified bowlder-clay, not in horizontal position, and varying in thickness from a few inches to a foot or more.

3. Bowlder-clay the same as number 1 , and containing similar bowlders but apparently bedded in some parts. In this division of the bowlder-clay series the following species of marine shells were found: Yoldia (Leda) arctica, abundant and well preserved, often with the epidermis on ; Belanus crenatus (fragments), Saxirava rugosa, Mya arenaria (a single valve), Macoma calcarea, Nucula tenuis (much broken), Buccinum sp. (?), probably undatum (a fragment), etc. All the species except Yoldia are quite rare. They appear to be indiscriminately'scattered through the mass. Thickness of this part of the bowlder-clay, 6 to 10 feet.

4. Stratified, dark red, tough clay, distinctly laminated, with a few bowlders of the same kinds of rocks as those met with in the unstratified portions; the deposit irregular and wavy, not in a horizontal position and somewhat lenticular, or rather not maintaining the same thickness for any distance. Layers of this division of the series are seen sometimes to run up obliquely into and terminate in the unstratified bowlder-clay immediately above, and in other places apparently to graduate into it. Scattered throughout are shells of Yoldia (Leda) arctica, well preserved, often in the bottom with the valves closed and the epidermis intact; Nucula tenuis (broken), Balanus crenatus (fragments), Saxicava rugosa, Macoma calcareä, Buccinum and Mya (fragments), and one or two undetermined species. Thickness, 4 feet.

5. The height of the whole bank here being about 45 feet, there still remain 19 or 20 feet of it below the stratified fossiliferous portion, number 4. For the space of some hundred yards both east and west of the section, however, this lower part is concealed from view by landslides. Nevertheless, it is evident that a thick bed of bowlder-clay underlies the stratified seam, number 4 ; whether containing other stratified layers and fossils it is at present impossible to say. No rock outcrops are visible, nor is the bottom of the bowlder-clay in sight anywhere in the vicinity of Negrotown point. The glaciation of Partridge island, which is in Saint John harbor, about a mile distant from Negrotown point, was apparently accomplished by the ice which moved out from the mainland. The ice which produced a portion at least of the bottom bowlder-clay 
must therefore have extended some distance beyond the present coast line; and from this fact the inference may be drawn that when it was deposited the land stood as high as at present relative to sea-level and perhaps higher.

\section{Fossil marine Shelds.}

Their Occurrence in the Bowlder-clay at Negrotown Point.-The first discovery of marine shells in the bowlder clay at Negrotown point was made by W. J. Wilson,* my assistant, in 1891. Heavy storms during the previous winter, accompanied by very high tides, had eroded and undermined the bank to such an extent as to cause landslips. and also to clean off the falling débris from the face of the slope, thus affording fresh exposures. The locality was examined by Baron Gerard de Geer, of the Swedish Geological Survey, and on several occasions since by myself, and I now feel certain the shells in the stratified portion of the bowlder-clay at least are in situ, and lived in the sea along this coast during the glacial period, and were entombed in these clays when the land stood considerably lower than at present.

In regard to the shells found in the unstratified bowlder-clay, some of them may have been pushed out in the deposits from the littoral into deeper waters by land ice. The presence of Mya arenaria in these beds along with Yoldia arctica, etc, may thus be accounted for. The irregular line of contact between the stratified and unstratified beds, the gradual changing of one into the other along this line. the fact of curving, irregular strata running up diagonally into the overlying unstratified mass in many places, all tend, in my judgment, to show that the unstratified fossiliferous bowlder-clay has also been deposited in its present situation beneath the sea.

Their Occurrence in the Bowlder-clay of the Saint Lawrence Valley.Marine shells have been found by Sir J. William Dawson in the bowlder-clay of the Saint Lawrence valley, at Isle Verte, Riviere du Loup, Murray bay and Saint Nicholas, $\dagger$ the species comprising Leda truncata of Brown, Yoldia arctica of Sars, Balanus hameri and Bryozea, the two latter adhering to bowlders and large stones, "evidencing," as the author says, "that they had for some time quietly reposed in the sea bottom before they were buried in the clay." +

* I have to acknowledge my indebtedness to W. J. Wilson, my assistant on the Geological Survey of Canada, for the collection of shells obtained from the bowider-clay at Negrotown point, and for timely and valuable observations which his residence in Saint John enabled him to make.

+ Notes on the post-Pliocene Geology of Canada: Can. Nat., 2 d series, vol, vi, 1872, p. 25.

f Till or bowlder-elay containing an intercalary fossiliferous seam of clay occurs at Portland, Maine. Professor C. H. Hitchcock gives a section of it in Geology of New Hampshire, part iii, p. 279 ; but the fossils found in it do not seem to have been kept separate from those collected in other beds in that vicinity called champlain, so that I am unable to correlate them with the fossils of the Saint John bowlder-clay. 
Their Occurrence in the Drumlins near Boston.-Warren Upham and others have discovered marine shells and fragments of shells in the bowlder-clay hills called "drumlins" near Boston.* His list shows, however, that the species are nearly all the same as those of the recent period. $\mathrm{Mr}$ Upham explains the occurrence of these shells in the drumlins by supposing that the ice of the glacial period ploughed up certain marine beds inclosing them to the north and carried them forward to form a portion of the material of these bowlder-clay hills.

Their Occurrence in the Leda Clay and Saxicava Sands of New Brunswick.Marine shells of Pleistocene age were found by G. F. Matthew and the writer a number of years ago in clays and sands on the coasts of the Bay of Fundy and Baie des Chaleurs, which have been correlated with the Leda clay and Saxicava sands of the Saint Lawrence valley. Lists of these shells were published in the reports of the Geological Survey of Canada, etc. $\dagger$ The height of the terraced deposits in which the shells occur clearly establishes the conclusion that when the lower fossiliferous portions were laid down the land stood from 180 to 220 feet lower than it is at the present day; and as the Leda clay and Saxicava sands containing these shells have invariably been found overlying the bowlderclay, it is naturally inferred that their deposition began about the close of the glacial period and occupied a distinct and separate interval of Pleistocene time.

\section{The Height of the Land and the Mode of Deposition of the} BOWLDER-CLAY.

It is a view generally held by glacialists who have studied the Pleistocene deposits and related phenomena of coast borders, especially within the glaciated belt, that the land was subsiding during the period of melting or retirement of the ice. The lower unstratified portion of the bowlder-clay here was probably deposited during the greatest advance of the land-ice; this ice, as shown on a previous page, having extended beyond Partridge island. It seems to have consisted mainly of sheets flowing out from the Saint John and Kennebeckasis valleys which may

\footnotetext{
* Proceedings of the Boston Soc. of Nat. Hist., vol. xxvi, 1888.

† Report of Progress, Geol. Surv. Canada, part EE, 1877-'78; Ann. Rep. Geol. Surv. Canada, vol. 1, part GG, 1885.

†J. D. Dana, Am. Jour Sci., third series, vol. ii, pp. 324-330; vol. v, pp. 198-211 ; vol. $x$, pp. 168-183, 409-438; vol. xxiv, pp. 98-104. J. W. Dawson, Bull. Geol. Soc. of America, vol. i, p. 318; Acadian Geology, supplementary note to fourth edition, 1891, p. 7. C. H. Hitcheock, Geology of New 'Hampshire, vol. iii, p. 279. Professor Hitchcock is, however, rather inclined to the view that it was the sea and not the land which ehanged level. Warren Upham, Bull. Geol. Soc. of America, vol. i, pp. 563-567. G. H. Stone, Am. Jour. Sci., vol, xl, pp. 122-144. Robert Chalmers, Ann. Rep. Geol. SurvCanada, vol. iv, 1888- 89 , pp. 10, $11 n$; Ganadian Naturalist, vol. x, p. 54. G. M. Dawson, Report of Prog. ess, Geol. Surv. Canada, 1877-'78, pp. 133-153 b.
} 
have been confluent, but there were also glaciers from the adjacent valleys and from the hills in the vicinity of Saint John harbor. The divergent courses of striæ recorded in this paper indicate that the discharge of these into the depression of the Bay of Fundy was not strictly contemporaneous, but successive, for no single body of ice moving out into an open bay would, in my judgment, be likely to produce striæ diverging $65^{\circ}$ to $67^{\circ}$ apart, even with the land more elevated than it now is. Moreover, independent of the striation of this particular locality, we have in the eastern provinces of Canada very good evidence of the existence and diverse movements of local glaciers throughout the whole glacial period.* What the height of the coast district was at the time this lower bowlder-clay was thrown down, however, cannot be determined with any degree of accuracy. In the later Tertiary it was 200 feet or more above the level at which it now stands relative to the sea. $\dagger$ It may be stated that not only Partridge island, but the islands of Campobello and Grand Manan, lying off the mouth of the Saint Croix river, have been overridden by the land-ice. The latter is now separated from the mainland by a strait or passage 45 to 50 fathoms deep and from 8 to 9 miles wide. $\ddagger$ Ice of such a comparatively local character as has been shown to have occupied the eastern provinces of Canada in the Pleistocene $\S$ could not, it seems to me, reach Grand Manan unless the land were higher relative to the sea than at present.

But whatever views may be entertained regarding the height of the land when the lower bowlder-clay referred to was deposited, the upper or overlying glacial deposits, stratified and unstratified, were evidently laid down when the subsidence of the land was in progress and had perhaps reached its maximum. The stratified fossiliferous portion, from its position and height above sea-level and the well-preserved condition of a number of its contained fossils, unequivocally proves that the coast must have then been from 100 to 200 feet lower than it now is. The retirement of the ice at this time, whether caused by the subsidence and consequent breaking away of its margin or by an amelioration of the clímate, or by both, does not seem to have been more than local, this supposition being at least sufficient to afford an explanation of all the facts. The irregular lenticular condition of the stratified portions and the fact of tongues of these being interstratified with the overlying unstratified bowlder-clay indicate with tolerable certainty that they must have been deposited as we now find them along or near the ice-front.

* Glaciation of Eastern Canada. R. Chalmers, Canadian Record of Science. Montreal, April, 1889. Ann. Rep. Geol. Surv. Canada, 1885 to 1889.

† Ann. Rep. Geol. Surv. Canada, yol, iv, 1888-'89, pp. 8, 9 n.

† Ann. Rep. Geol. Surv. Canada, vol. iv, 1888-'89, pp. $48,49 n$.

\& R Chalmers, Ann. Reports Geol. Surv. Canada, 1885 to 1889. Trans. Roy. Soc. of Canada, 1886, sec. 4, art. 10. Canadian Record of Seience, April, 1889, pp. 319-333. 


\section{OscillaAtions of The ICE-Margin.}

It is abundantly clear that there have been several oscillations of the ice-margin. Not only do the stratified seams and irregular, roughly horizontal breaks in places in the upper portion of the bowlder-clay show such advances and recessions of the ice, but the divergent courses of striæ likewise denote several ice-movements as stated and indicate that the bottom portion of the bowlder-clay has been formed by a number of successive accretions or additions of material. The whole of the bowlder-clay in question would seem, indeed, to have been produced in a zone of oscillation of the ice-front, the ice retiring to and advancing from the Carleton and other hills to the north. The later advances were comparatively light, otherwise the older or first-formed beds would have been ploughed up much more deeply than they are. This may, however, be partly due to the continued subsidence, which at the close of the glacial or commencement of the Leda-clay period amounted to 220 feet below the present high-tide level, in which case these deposits may really have been thrown down in a sea of considerable depth.

\section{Chimatic Conditions during Deposition of the Leda Clay and SaXicava SANDS.}

The deposition of the Leda clay closely followed the last recession of the ice and may, indeed, have been in progress before it finally disappeared from the hills around the mouth of the Saint John. The Ledaclay fauna here does not denote such arctic conditions as prevailed in the latter part of the glacial period, nor, indeed, in the Leda-clay period in the gulf of Saint Lawrence. This has been shown by G. F. Matthew and by Sir J. William Dawson.* The amelioration of climate following the retreat of the ice was coincident with a rising of the land, as indicated by the facies of the marine fauna found in the clays deposited in the quieter bottoms and of that of the sands, etc, in the shallower sea margins during the Leda-clay and Saxicava-sand period. No glacial deposits are known to overlie these, or be interstratified with them, on the Atlantic coast of Canada.

\section{Conclustons.}

The conclusions drawn from the foregoing facts may therefore be thus briefly summarized:

1. The bowlder-clay here described was deposited at or near the margin of the land ice which flowed out from the Saint John and Kennebeckasis

* Notes on the post-Pliocene Mollusca of Acadia: G. F. Matthew, Canadian Naturalist, vol, viij. supplement to the 2d ed. of Asadian Geology, 1878.

LV-BUH,. GEOI, SOC. AM, Vor, 4, 1892. 
valleys, etc. The ice-front was beneath the sea at the time the stratified and overlying, unstratified fossiliferous portions were deposited. These testify very clearly to several local oscillations of the ice-front and show unmistakably that this portion of the series was formed by a number of successive increments or additions of material, appearing, indeed, just as if the ice had "dumped" it a number of times in succession over the Carleton hills into the Pleistocene sea with little or no disturbance of the preëxisting beds.

2. The'shells in the stratified portions of the bowlder-clay are in situ, and have been entombed in it in a sea 100 to 200 feet or more in depth. They are in too perfect a condition to have been transported in bowlderclay by ice, and, moreover, the state of the beds in which they occur is opposed to this view. Those found in the overlying, unstratified bowlder-clay may have had the shallow-water species now found buried in it pushed out from the Pleistocene shore and thus mingled with the deepwater forms. All the species denote an arctic or a subarctic climate and a sea even colder than existed at the beginning of the Leda-clay period.

3. The land on this part of the Bay of Fundy coast during the deposition of this fossiliferous bowlder-clay must have been, therefore, 100 to 200 feet or more lower than at the present day, relative to the sea.

4. As the striæ on the rocks underneath the bowlder-clay indicate several ice movements varying in direction from $\mathrm{S}, 2^{\circ} \mathrm{W}$. to $\mathrm{S} .65^{\circ} \mathrm{E}$., these and the formation of the lower bowlder-clay cannot all be due to one body of ice. The latter is therefore the product of several glaciers, each successive one having worked over all the material beneath it down to the rock surface.

\section{DISCUSSION.}

Mr WarRen Upham: The occurrence of Yoldia arctica as the only plentiful species in the intercalated stratified seams of clay met with in the bowlder-clay at Saint John implies that the margin of the ice was near when it inhabited the Bay of Fundy waters. This shell is now found living only in the Arctic ocean, and thrives most, according to Baron de Geer, in Spitzbergen, near the mouths of streams discharged from glaciers and muddy with the fine silt due to their erosion. 


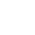

